\title{
Impact of Online Learning Application and Lecturer Performance on Student Learning Motivation at Faculty of Economics and Business Warmadewa University
}

\author{
I Made Setena*, Ni Putu Sri Mariyatni and I. A. Sri Meitri \\ Universitas Warmadewa, Denpasar-Bali, Indonesia \\ *Email:madesetena@gmail.com
}

\begin{tabular}{|l|}
\hline \\
\hline How to cite (in APA style): \\
Setena, I, M., Mariyatni, N, P, S., Meitri, I, A, S. (2021). Impact of Online Learning Application and Lecturer Performance \\
on Student Learning Motivation at Faculty of Economics and Business Warmadewa University. Jurnal Ekonomi dan \\
Bisnis Jagaditha, 8(2), 157-163. doi: https://doi.org/10.22225/jj.8.2.2021.157-163
\end{tabular}

\begin{abstract}
Motivation in learning has a role to foster a sense of pleasure, passion, and enthusiasm for learning. The lack of learning motivation in distance learning is caused by the process of learning, where students can become less active in conveying their opinions and thoughts, causing a boring learning process. Student learning motivation is also influenced by lecturer performance. The purpose of this study was to examine student learning motivation in online learning at the Faculty of Economics and Business, Warmadewa University. Various methods are applied in distance learning activities, including the google meet application, zoom application, google classroom, youtube, television, and whatsapp social media. Data was collected by distributing questionnaires which were used as research instruments. Sampling was carried out using the saturated sample method or the census method, namely 48 students who took financial management courses as respondents. To test the research instrument, validity and reliability were tested. Classical Assumption Test is used to test the Regression model. Data analysis used multiple linear regression analysis. The results of the analysis show that the application of online learning and lecturer performance has a positive and significant impact simultaneously or partially on student learning motivation at the Faculty of Economics and Business, Warmadewa University. Thus, it can be suggested that to support learning more effectively, it is better to use more varied learning methods and learning support facilities need more attention.
\end{abstract}

Keywords: learning motivation; lecturer performance; online learning

\section{INTRODUCTION}

The implementation of education in Indonesia during the Covid-19 pandemic underwent several visible changes. Dewey (2001) argued that education is an endless process (education is the process without end), and education is a process of forming basic skills that are fundamentally good. concerns the power of thought, intellectual and emotional power, feelings that are directed to human nature and to each other. Therefore, the learning process is the key to the success of education so that the learning process becomes quality, (Simamora, 2006). Based on that statement, education must run under any circumstances. To reduce the spread of Covid19 and education activities can run as usual, the government has made several efforts to reduce this number, one of which is by implementing a teaching and learning system with an online system since March 2020.

Online learning or e-learning is an important part of distance education as mandated in Law No. 12 of 2012 concerning Higher Education. Online learning (e-learning) is defined as individual/independent or group learning using information and communication technology (ICT) and networks that provide flexibility for students to learn anytime, anywhere, and with anyone. This online learning can be combined with conventional 
face-to-face or blended learning, but has innovative value, because it provides a new nuance in the teaching and learning process that is different from regular face-to-face learning. Circular Letter of the Minister of Education and Culture No. 3 of 2020 concerning Prevention of Covid-19 in Education Unit on March 9, 2020; Minister of Health Circular No. HK.02.01/ MENKES/199/2020 on March 12, 2020; and Circular of the Secretary General of the Ministry of Education and Culture No. 36603/ A.A5/OT/2020 on March 15, 2020, (Martoyo, 2007:42). Changes in the education sector require lecturers to adjust the implementation of learning in accordance with the demands of development (ICT) and is one of the points of professional competence required must have. Various facilities are used by educators to carry out distance learning activities. The learning facilities include the Google Meet application, the Zoom application, Google Classroom, YouTube, television, and WhatsApp social media. Where all these facilities are produced from the increasingly advanced development of ICT. However, with a learning system, long distance does not rule out the possibility of several obstacles in the learning process, such as weak signals, servers that are down and difficult to access, additional internet quota fees, lack of communication and socialization between students and lecturers, unlimited teaching hours for lecturers, mastery of e-learning which is still lacking, the mastery of the material is lacking, especially in practical courses, this can affect the learning motivation of students or students.

Motivation in learning has a role to foster a sense of pleasure, passion, and enthusiasm for learning. The lack of learning motivation in distance learning is caused by the process of learning, where students can become less active in conveying their opinions and thoughts, causing a boring learning process. If students experience boredom in learning, it will have an impact on learning outcomes. Therefore, motivation or encouragement is needed to move students so that the spirit of learning can have learning achievements. This is reinforced by the results of research conducted by Fitriyani et al. (2020), which found that in the midst of the Covid-19 pandemic that hit the world, it was not a reason for students to remain motivated in learning even though there were several obstacles in its implementation, (Khafidhoh, 2015).

Student learning motivation is also influenced by lecturer performance. Lecturers are professional educators and scientists with the main task of transforming, developing, and disseminating science, technology, and art through education, research, and community service, (Subagyo, 2014). To carry out these very strategic functions, roles, and positions, lecturers are needed. professional and have quality performance. Without sufficient mastery of technology, lecturers will have difficulty producing the innovations that students need to be able to take optimal advantage through active involvement in online learning.

So far, the learning process at Warmadewa University, especially the Faculty of Economics and Business has been running according to the learning process in general, namely face-to-face in class between lecturers and students. However, in line with the Covid19 pandemic, lectures were carried out using an online system as a substitute for face-toface lectures. Based on the implementation of online lectures, of 48 Faculty of Economics and Business, Warmadewa University students who took financial management courses, there were several complaints such as weak signals, limited communication between students and lecturers, giving a lot of assignments, lack of understanding of the material presented and the one-way learning process is very difficult to discuss.

There are several related studies have conducted previously about online learning and students' motivation. Mandasari (2020) in her study about the impact of online learning toward students' academic performance on Business Correspondence course found that online learning has positive impact on students' academic performance in term of learning motivation, learning achievement and learning engagement. In addition, it was also found that participants showed that conducting online learning is relevant during pandemic. Furthermore, flexibility, accessibility, learning autonomy, and boosting students' achievement become the strengths of conducting online learning. However, financial issue and bad internet access become problems that hamper online learning. Gustiani (2020) in her study about students' motivation in online learning during covid-19 pandemic era revealed that the students' motivation toward their online learning was intrinsically affected more by their ambition to learn new knowledge and enjoyment in experiencing new learning method. It was also influenced extrinsically by external regulation and environmental condition. However, a motivation or the state 
of lack motivation also happened due to poor external supporting facilities. The different result about the effect of online learning on university students' learning motivation have been found by Mardesci (2020) that revealed that students shared negative learning motivation responses to online learning. Therefore, based on the explanation and the gap of the previous study explained above, this study aims to examine student learning motivation in online learning at the Faculty of Economics and Business, Warmadewa University.

\section{CONCEPTUAL FRAMEWORK}

\section{Learning Motivation}

Learning motivation is a process that gives enthusiasm, direction, and persistence of behavior in learning activities. A person's motivation will be good, if the goal in a person is good. In the context of learning, the goal from within students is to get maximum learning outcomes. Students who have strong motivation will have a lot of energy and enthusiasm to participate in learning activities.Learning motivation is an encouragement in learning activities, so that motivation can be said as the overall driving force in students that creates, ensures continuity and provides direction for learning activities, so that it is hoped that goals can be achieved, (Kim, Kim, \& Kim, 2017).

\section{Factors Affecting Learning Motivation}

Learning motivation can arise due to intrinsic and extrinsic factors. Intrinsic factors that influence learning motivation are: (1) the desire and desire to succeed and the encouragement of learning needs, (2) the hope for ideals ". Extrinsic factors that influence learning motivation include: (1) first, there is an award, (2) a conducive learning environment, (3) interesting learning activities" (Uno, 2011:23).

\section{Learning Motivation Indicator}

To determine the strength of student learning motivation can be seen from several indicators as follows: 1) Strong will to do. 2) The amount of time devoted to study. 3) Willingness to leave other obligations/duties. 4) . Perseverance in doing the task (Handoko, 1992:59).

\section{Online Learning}

Online learning is learning that uses the internet network with accessibility, connectivity, flexibility, and the ability to create various types of learning interactions
(Moore, Dickson-Deane, \& Galyen, 2011). Online learning is learning that is able to bring together students and lecturers to carry out learning interactions with the help of the internet (Kuntarto, 2017).

\section{Impact of Online Learning}

Online learning has several positive impacts, including: a) Increasing learning interactions between students and teachers (enhance interactivity). b) Allows learning anywhere and anytime (time and place flexibility). c) Reaching out to students in a broad scope (potential to reach a global audience). d) Facilitate storage and improvement in learning (easy updating of content as well as archivable capabilities). e) Building Community (Bates, 1995; Wulf, 1996).

\section{Online Learning Indicators}

Learning is said to be effective if it reaches the desired target, both in terms of learning objectives and maximum student achievement. Several indicators of learning effectiveness: a. achievement of complete learning, b. the achievement of the effectiveness of student activities (ie the achievement of the ideal time used by students to carry out each activity contained in the lesson plan), c. the achievement of the effectiveness of the teacher's ability to manage learning, and student responses to positive learning (Saadi, Halidjah, \& Kartono, 2013).

\section{Lecturer Performance}

Lecturers are professional educators and scientists with the main task of transforming, developing, and disseminating science, technology, and art through education, research, and community service (Subagyo, 2014).

\section{Lecturer Performance Indicator}

Performance indicators can be seen from the ability to master the competence of lecturers. The competencies that must be possessed include: 1) Pedagogics: The ability to manage student learning, design and implementation of learning, evaluation of results learning, and developing students to actualize their various potentials. 2) Personality: Personality abilities that are steady, stable, mature, wise and authoritative, become role models for students, and have noble character. 3) Professional: The ability to master learning materials broadly and deeply which allows them to guide students to meet competency standards. 4) Social: The ability of educators as part of the community to 
communicate and interact effectively with students, fellow educators, education staff, parents/guardians of students, and the surrounding community (Subagyo, 2014).

\section{METHOD}

The place of research was carried out on students of the Faculty of Economics and Business, Warmadewa University, while the objects of research were: Online Learning, Lecturer Performance, Student Learning Motivation. The population in this study were 48 students of the Faculty of Economics and Business, University of Warmadewa who took financial management courses. The number of samples used is a population of 48 people using the census method. The saturated sample or census technique is used if all the population is used as respondents, provided that the population is less than 100 people (Arikunto, 2012:104). The method used in this study is a qualitative data, which is the respondent's perception of the variables being tested. Based on the source, the data used are primary data in the form of opinions from research subjects collected using survey methods through questionnaires. The data is quantified by giving a score to each respondent's answer. Likert scale is used to measure attitudes, opinions, and perceptions of a person or group of people about social phenomena. Each answer to the questionnaire has a weight or score. Furthermore, respondents' answers are scored and analyzed by multiple linear regression analysis.

\section{RESULTS AND DISCUSSION}

This study discussed the student learning motivation in online learning at the Faculty of Economics and Business, Warmadewa University. The data of this study were obtained from the results of respondents' answers in the form of statements, namely the distribution of questionnaires to 48 the Faculty of Economics and Business, Warmadewa University students who took financial management courses. Therefore, the characteristics of respondents are described below.

\section{Characteristics of Respondents}

Characteristics of respondents obtained in the process of distributing questionnaires, so in this study will be analyzed the relationship between the characteristics of respondents, namely: gender and age.

\section{Characteristics of Respondents by Gender and Age}

Based on table 1 shows that most of the students or respondents are male, as many as $45.83 \%$ and $54.17 \%$ are female, while the age ranges from 17 to 19 years.

Table 1. The Characteristics of Respondents by Gender and Age

\begin{tabular}{llll}
\hline Gender & Amount & Percentagee & Age \\
\hline Man & 22 People & $45,83 \%$ & 17 s/d 19 Years Old \\
Girl & 26 People & $54,17 \%$ & \\
Amount & 48 People & $100 \%$ & \\
\hline
\end{tabular}

Source: Faculty of Economics and Business, Warmadewa University

\section{Validity and Reliability Test Results}

Validity Test

The results of the validity test of online learning variable indicators, lecturer performance, Faculty of Economics and Business, Warmadewa University student learning motivation, all variables have product moment correlation coefficient values above 0.3 so that it can be said that all research instruments are valid.

\section{Reliability Test}

Reliability test is a tool to measure a questionnaire which is an indicator of a variable or construct. A questionnaire is said to be reliable or reliable if a person's answer to the statement is consistent or stable from time to time (Ghozali, 2011). In this test, measuring the variables by looking at the Cronbach Alpha with a significance $>$ of 0.70 . A variable is said to be reliable if the Cronbach Alpha value is $>$ 0.70 (Ghozali, 2011). The results of the reliability test showed that all Cronbach alpha values were $>0.70$. This means that the statement items used will be able to obtain consistent data in the sense that if the statement is submitted again, an answer that is relatively the same as the first answer will be obtained.

\section{Classical Assumption Test}

To be able to use Multiple Linear Regression analysis, the regression model was tested with the classical assumption test as follows: 


\section{Normality test}

The normality test of the data carried out means that all data are normally distributed, this can be seen from the results of the Kolmogorov-Smirnov test the value of Asymp.Sig (2-Tailed) is greater than 0.05, namely 0.626 , so it can be interpreted that all data are normally distributed.

\section{Multicollinearity Test}

The results of the calculation of the VIF value less than 10 and the tolerance number greater than 0.1 and showing a tolerance value of 0.361 each so that there is no independent variable whose tolerance value is less than 0.1 or the variance inflation factor is less than 10 , it is concluded that there is no multicollinearity between the independent variables in the regression model.

\section{Heteroscedasticity Test}

Based on Scatterplot it is known that the variable data has a random distribution, there is no certain pattern on the scatterplot graph, meaning that the regression model does not occur heteroscedasticity.

\section{Multiple Linear Regression Analysis}

Table 2. Multiple Linear Regression Analysis Results Coefficientsa

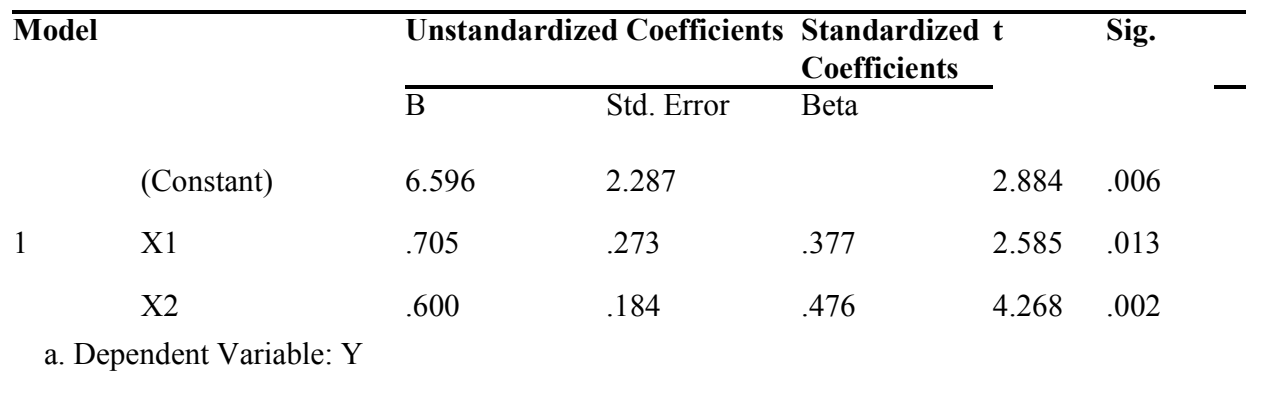

Based on table 2 above, the equation of the multiple linear regression line between incentives and social security on employee productivity is obtained: $\mathrm{Y}=6.596+0.705 \mathrm{X} 1$ $+0.600 \mathrm{X} 2$. This means that the increase in student learning motivation is influenced by the increase in online learning and lecturer performance together.

\section{F-test}

Based on the results of the analysis in accordance with the test criteria F-count = $42.797>$ F-table $=2.84$, this means that simultaneously online learning and lecturer performance have a positive and significant influence on student learning motivation.

\section{t-test}

Based on the results of the analysis, it is known that the calculated t1-value is $2.585>$ t1-table is 1.684 with a significant level of $0.010<0.05$. It can be concluded that the online learning variable partially has a positive and significant effect on students' learning motivation. Based on the results of the analysis, it is known that the calculated t2 value is $4.157>$ t2-table is 1.684 with a significant level of $0.010<0.05$. It can be concluded that the lecturer's performance variable partially has a positive and significant effect on students' learning motivation

The regression equation formed based on the results of multiple analysis is $\mathrm{Y}=6.596+$
$0.705 \mathrm{X} 1+0.600 \mathrm{X} 2$. explains that a (constant value), b1 (coefficient of online learning X1), and b2 (coefficient of lecturer performance $\mathrm{X} 2$ ) The multiple linear regression equation shows a positive direction between online learning and lecturer performance on student learning motivation. Thus, it can be stated that the level of student learning motivation is jointly influenced by online learning and lecturer performance.

The F-test test is a test of the significance of the multiple linear regression coefficients obtained F-count $=42.797>$ F-table $=2.84$, indicating that it is true that there is a simultaneous significant effect between online learning and lecturer performance on student learning motivation and not obtained by chance.

The significance test using t-test obtained t-count values for online learning variables and lecturer performance of 2.585 and 4,157 respectively $>\mathrm{t}$-table 1.684 , indicating that it is true that there is a positive and partially significant effect between online learning and lecturer performance on student learning motivation and not obtained by chance.

\section{CONCLUSIONS}

Grounded by the results and discussion explained above, thus it can be concluded that the application of online learning and the performance of lecturers have a positive and 
significant simultaneous effect on the learning motivation of Faculty of Economics and Business, Warmadewa University students; this is evident from the results of the F test. So, the hypothesis that the application of online learning and lecturer performance has a significant simultaneous effect on the learning motivation of Faculty of Economics and Business, Warmadewa University students is proven the truth. Moreover, the application of online learning and lecturer performance have a positive and significant partial effect on the learning motivation of Faculty of Economics and Business, Warmadewa University students, this is evident from the results of the $t$ test. So the hypothesis that the application of online learning has a significant effect on the learning motivation of Faculty of Economics and Business, Warmadewa University students and the performance of lecturers has a significant effect on the learning motivation of Faculty of Economics and Business, Warmadewa University students is proven true. Based on this, it can be suggested that the application of online learning and the performance of lecturers to the learning motivation of Faculty of Economics and Business, Warmadewa University students as a whole is in a good category, but for a more effective application of learning or teaching and learning processes, it should be reviewed using more varied learning methods, and learning support facilities need more attention. Seriously, the ability of lecturers in transforming material to students needs to be improved.

\section{REFERENCES}

Arikunto, S. (2012). Prosedur Penelitian Suatu Pendekatan Praktek. Jakarta: Rineka Cipta.

Bates, A. W. (1995). Technology, Open Learning and Distance Education. London: Routledge.

Dewey, J. (2001). Democracy and Education. Pennsylvania: A Penn State Electronic Classics Series Publication.

Fitriyani, Y., Fauzi, I., \& Sari, M. Z. (2020). Motivasi Belajar Mahasiswa Pada Pembelajaran Daring Selama Pandemik Covid-19. Jurnal Kependidikan: Jurnal Hasil Penelitian Dan Kajian Kepustakaan Di Bidang Pendidikan, Pengajaran Dan Pembelajaran, 6(2), $165 . \quad$ https:// doi.org/10.33394/jk.v6i2.2654

Ghozali, I. (2011). Aplikasi Analisis Multivariate Dengan Program IBM SPSS19. Semarang: Badan Penerbit Universitas Diponegoro.

Gustiani, S. (2020). Students 'Motivation in Online Learning During Covid-19 Pandemic Era : a Case Study. Holistics Journal, 12(2), 23-40.
Retrieved from https://jurnal.polsri.ac.id/ index.php/holistic/article/view/3029

Handoko, M. (1992). Motivasi Daya Penggerak Tingkah Laku. Yogyakarta: Kanisius.

Khafidhoh, S. (2015). Pengaruh Insentif Dan Jaminan Sosial Terhadap Produktivitas Kerja Karyawan Kantor Pada PT. Rea Kaltim Plantations di Samarinda. EJournal of Business Administration, 3(3), 587-599. Retrieved from http://ejournal.adbisnis.fisipunmul.ac.id/site/?p=1120

Kim, H. B., Kim, S., \& Kim, T. T. (2017). The Selection and Causal Effects of Work Incentives on Labor Productivity: Evidence from a Two $\square$ stage Randomized Controlled Trail in Malawi. Retrieved from https:// www.iza.org/publications/dp/10644/theselection-and-causal-effects-of-workincentives-on-labor-productivity-evidencefrom-a-two-stage-randomized-controlledtrial-in-malawi

Kuntarto, E. (2017). Keefektifan Model Pembelajaran Daring Dalam Perkuliahan Bahasa Indonesia di Perguruan tinggi. Journal Indonesian Language Education and Literature, 3(1), 53-65. https://doi.org/ http://dx.doi.org/10.24235/ileal.v3i1.1820

Mandasari, B. (2020). The Impact of Online Learning toward Students' Academic Performance on Business Correspondence Course. EDUTECn Journal of Education And Technology, 4(1), 98-110. https:// doi.org/10.29062/edu.v4i1.74

Mardesci, H. (2020). The Effect of Online Learning on University Students' Learning Motivation. JPP (Jurnal Pendidikan Dan Pembelajaran), 27(1), 42-47. https:// doi.org/10.17977/um047v27i12020p042

Martoyo, S. (2007). Manajemen Sumber Daya Manusia (Edisi ke 5). Yogyakarta: BPFE.

Moore, J. L., Dickson-Deane, C., \& Galyen, K. (2011). e-Learning, online learning, and distance learning environments: Are they the same? The Internet and Higher Education, 14(2), 129-135. https://doi.org/10.1016/ j.iheduc.2010.10.001

Saadi, F., Halidjah, S., \& Kartono. (2013). Peningkatan Efektivitas Belajar Peserta Didik dalam Pembelajaran Ilmu Pengetahuan Sosial Menggunakan Media Tepat Guna di Kelas IV Sekolah Dasar Negeri 02 Toho. Jurnal Pendidikan Dan Pembelajaran Khatulistiwa, 2(7). Retrieved from https://jurnal.untan.ac.id/index.php/ jpdpb/article/view/2460

Simamora, H. (2006). Manajemen Sumber daya Manusia. Yogyakarta: STIE YKPN Publishing Section Bagian.

Subagyo, B. (2014). Pengaruh Pemberian Insentif Terhadap Produktivitas Kerja Karyawan Pada Rumah Sakit Aisyah Blitar. Arthavidya Jurnal Ilmiah Ekonomi, 16(2). https:// doi.org/https://doi.org/10.37303/a.v16i2.60 
Impact of Online Learning Application and Lecturer Performance on Student Learning Motivation at Faculty of Economics and Business Warmadewa University

Uno, H. B. (2011). Teori Motivasi dan Pengukurannya, Analisis di Bidang Pendidikan. Jakarta: PT. Bumi Aksara.

Wulf, K. (1996). Training via the Internet: Where Are We? Training \& Development, 50, 5055. 